University of South Florida

DIGITAL COMMONS

Digital Commons @ University of

@ UNIVERSITY OF SOUTH FLORIDA

South Florida

$1-2012$

\title{
First Year Morphological Evolution of an Artificial Berm at Fort Myers Beach, Florida
}

Katherine Brutsche

University of South Florida, kebrutsche@usf.edu

Ping Wang

University of South Florida, pwang@usf.edu

Follow this and additional works at: https://digitalcommons.usf.edu/gly_facpub

Part of the Geology Commons

\section{Scholar Commons Citation}

Brutsche, Katherine and Wang, Ping, "First Year Morphological Evolution of an Artificial Berm at Fort Myers Beach, Florida" (2012). Geology Faculty Publications. 257.

https://digitalcommons.usf.edu/gly_facpub/257

This Statistical Report is brought to you for free and open access by the Geology at Digital Commons @ University of South Florida. It has been accepted for inclusion in Geology Faculty Publications by an authorized administrator of Digital Commons @ University of South Florida. For more information, please contact digitalcommons@usf.edu. 


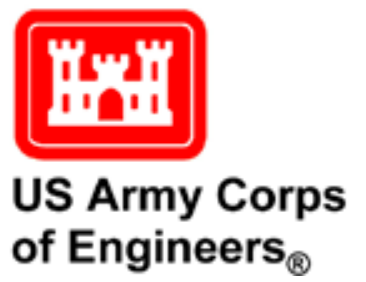

\section{First Year Morphological Evolution of an Artificial Berm at Fort Myers Beach, Florida} by Katherine E. Brutsche and Ping Wang

PURPOSE: This Coastal and Hydraulics Engineering Technical Note (CHETN) documents the sediment characteristics and first year morphological evolution of an artificial berm placed just offshore in Fort Myers Beach, Florida, based on a series of field data collection periods during the first year after the berm construction.

INTRODUCTION: Maintenance dredging is a common practice in inlets and channels for navigation. As a part of regional sediment management, the dredged material is often used for nearby shore protection. One method is placing sand directly on the adjacent beach. The other is placement of a nearshore berm, i.e., to add sediment to the littoral system and/or act as a breakwater to dissipate wave energy and slow erosion (Allison and Pollock, 1993). Compared to beach fill, berm nourishment may have the advantage of being less costly with more lenient restrictions on the dredged material.

Artificial nearshore berms can be categorized depending on their dynamics or intended purpose. Hands and Allison (1991) defined two types of berms based on mobility. Stable berms are those that remain at the placement site and retain most of their volume over several years. Active berms show movement and changes within a few months. Hands and Allison (1991) and Hallermeier (1981) suggested that wave climate and closure depth are good indicators of whether a berm would be active or stable. Aidala et al. (1996) and Work and Otay (1996) indicated that bottom shear stress and horizontal bed velocities are also good indicators of berm stability.

McLellan and Kraus (1991) describe design guidance for two different types of berm: a feeder berm and a stable berm. A Feeder berm is placed in such a way that under accretionary wave action, sediment will be added to the shore from the berm. A Stable berm is intended to be a semi-permanent feature that attenuates high energy waves and may also serve as a fish habitat. McLellan and Kraus (1991) suggested several criteria to be considered during the berm design, including timing of placement, depth and length of berm, location of placement, and sediment grain size. Larson and Kraus (1992) developed empirical formulas to predict onshore or offshore movement of a berm.

Matanzas Pass (Figure 1), located along Fort Myers Beach at the northern tip of Estero Island in west-central Florida, is a federally maintained navigation channel. The inlet has been dredged in 1986, 1996, and 2001, with the dredged sand placed along the adjacent beaches, as well as in the nearshore zone. Since the dredging in 2001, the channel had shoaled to the extent of blocking the entire channel, which prompted a new dredging cycle in 2009 (Florida Department of Environmental Protection, 2009). A hydraulic dredge was used and the material was placed in the form of a nearshore berm, 1.5 miles southeast of the dredging area (Figure 2). This report documents the sediment characteristics of the berm and examines the first year morphologic evolution. 


\section{Report Documentation Page}

Form Approved

OMB No. 0704-0188

Public reporting burden for the collection of information is estimated to average 1 hour per response, including the time for reviewing instructions, searching existing data sources, gathering and maintaining the data needed, and completing and reviewing the collection of information. Send comments regarding this burden estimate or any other aspect of this collection of information,

including suggestions for reducing this burden, to Washington Headquarters Services, Directorate for Information Operations and Reports, 1215 Jefferson Davis Highway, Suite 1204, Arlington

VA 22202-4302. Respondents should be aware that notwithstanding any other provision of law, no person shall be subject to a penalty for failing to comply with a collection of information if it

does not display a currently valid OMB control number.

\begin{tabular}{|c|c|}
\hline $\begin{array}{l}\text { 1. REPORT DATE } \\
\text { JAN } 2012\end{array}$ & $\begin{array}{l}\text { 3. DATES COVERED } \\
\mathbf{0 0 - 0 0 - 2 0 1 2} \text { to 00-00-2012 }\end{array}$ \\
\hline \multirow{3}{*}{$\begin{array}{l}\text { First Year Morphological Evolution Of An Artificial Berm At Fort Myers } \\
\text { Beach, Florida }\end{array}$} & 5a. CONTRACT NUMBER \\
\hline & 5b. GRANT NUMBER \\
\hline & 5c. PROGRAM ELEMENT NUMBER \\
\hline \multirow[t]{3}{*}{ 6. AUTHOR(S) } & 5d. PROJECT NUMBER \\
\hline & 5e. TASK NUMBER \\
\hline & 5f. WORK UNIT NUMBER \\
\hline $\begin{array}{l}\text { 7. PERFORMING ORGANIZATION NAME(S) AND ADDRESS(ES) } \\
\text { U.S. Army Engineer Research and Development Center,Coastal and } \\
\text { Hydraulics Laboratory,Vicksburg,MS,39180 }\end{array}$ & $\begin{array}{l}\text { 8. PERFORMING ORGANIZATION } \\
\text { REPORT NUMBER }\end{array}$ \\
\hline \multirow[t]{2}{*}{ 9. SPONSORING/MONITORING AGENCY NAME(S) AND ADDRESS(ES) } & 10. SPONSOR/MONITOR'S ACRONYM(S) \\
\hline & $\begin{array}{l}\text { 11. SPONSOR/MONITOR'S REPORT } \\
\text { NUMBER(S) }\end{array}$ \\
\hline
\end{tabular}

12. DISTRIBUTION/AVAILABILITY STATEMENT

Approved for public release; distribution unlimited

13. SUPPLEMENTARY NOTES

14. ABSTRACT

Maintenance dredging is a common practice in inlets and channels for navigation. As a part of regional sediment management, the dredged material is often used for nearby shore protection. One method is placing sand directly on the adjacent beach. The other is placement of a nearshore berm, i.e., to add sediment to the littoral system and/or act as a breakwater to dissipate wave energy and slow erosion (Allison and Pollock, 1993). Compared to beach fill, berm nourishment may have the advantage of being less costly with more lenient restrictions on the dredged material.

\section{SUBJECT TERMS}

16. SECURITY CLASSIFICATION OF:

a. REPORT

unclassified b. ABSTRACT unclassified c. THIS PAGE unclassified
17. LIMITATION OF ABSTRACT

Same as Report (SAR)
18. NUMBER OF PAGES

9a. NAME OF

11 RESPONSIBLE PERSON 


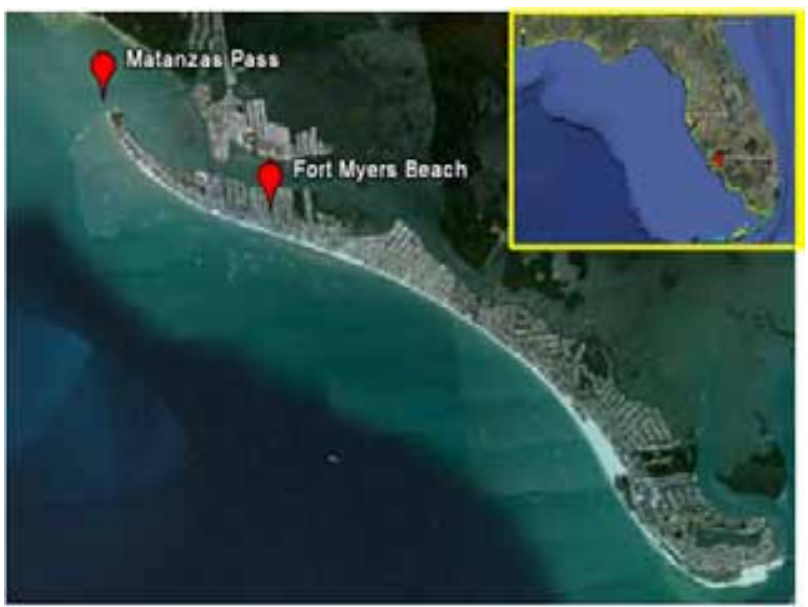

Figure 1. Fort Myers Beach and Matanzas Pass at the north end of Estero Island, Florida.

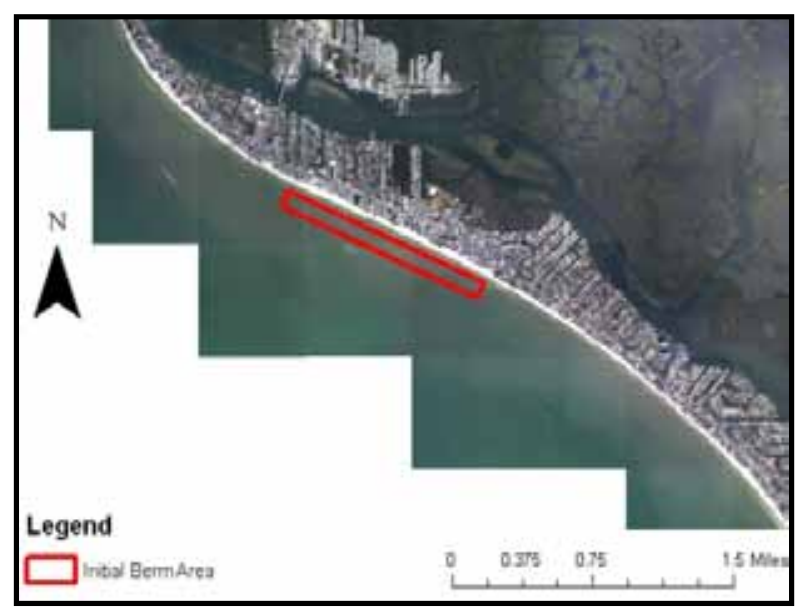

Figure 2. Designed berm placement location.

BERM CONSTRUCTION: The 2009 Fort Myers Beach berm was constructed using material dredged from Matanzas Pass. An 18" suction cutter dredge was used and the material was placed roughly $600 \mathrm{ft}$ offshore in $6 \mathrm{ft}$ water depth. Considerable longshore variation of the berm height occurred during the construction. The dredging took place in 3 stages. In Stage 1, the shoaled upland material at the northeastern tip of Estero Island, located within the previous navigation channel, was dredged. The Stages 2 and 3 dredging included the shoaled channel offshore and along the bay side of the island, respectively. Fill began in the northern portion of the project area during Stage 1 and moved south. Several gaps of less than $50 \mathrm{ft}$ wide were left during the construction.

METHODOLOGY: This study is based on sediment and morphology data collected in the first year. An initial post-construction survey was conducted by the Jacksonville District (USACE) in October 2009. Since April 2010, an intensive field data collection method was conducted by the Coastal Research Lab at the University of South Florida (USF). The USF study area includes the artificial berm area and control areas 1 mile northwest and southeast of the berm, respectively (Figure 3). Beach profiles in the control areas were set at roughly $600 \mathrm{ft}$ intervals, while lines over the artificial berm were set at about $150 \mathrm{ft}$ intervals. The 57 beach profiles, extending to roughly $8 \mathrm{ft}$ water depth, were surveyed using an electronic total station following standard level-transect procedures. Two time-series surveys were conducted in April 2010 and October 2010. Surface sediment samples were collected along 11 of the 57 beach profiles, including 5 across the artificial berm and 6 in the control areas (Figure 4).

GENERAL OCEANOGRAPHIC AND METEOROLOGICAL CONDITIONS: The study area is influenced by a mixed tide regime. Spring tides tend to be diurnal with a range of nearly $4 \mathrm{ft}$, while neap tides are semi-diurnal ranging about 2 to $2.5 \mathrm{ft}$ (Figure 5). Waves in the study area are mostly generated by local winds, except during rare extreme events such as tropical storms. Table 1 summarizes the post construction wind conditions from October 2009 to October 2010 , including only onshore-directed winds. Onshore wind, averaging slightly less than $13 \mathrm{ft} / \mathrm{sec}(9 \mathrm{mph})$, occurs 32 percent of the time. The relatively stronger winds approach from southeast (130-175 degrees) and northwest (266-310 degrees). These winds are highly oblique relative to the shoreline orientation (130-310 strike). The overall intensities and occurrences of 


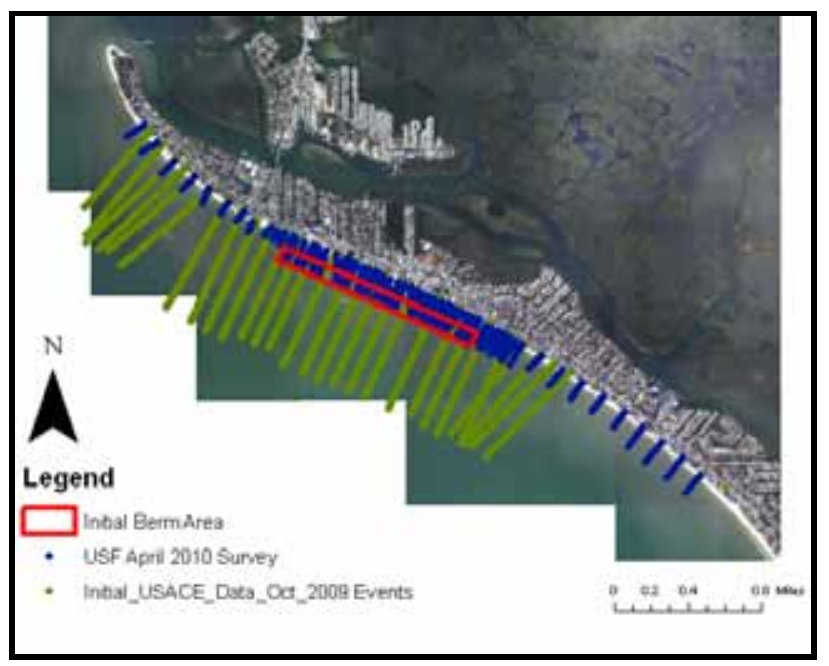

Figure 3. USACE (including offshore survey) and USF survey line locations.

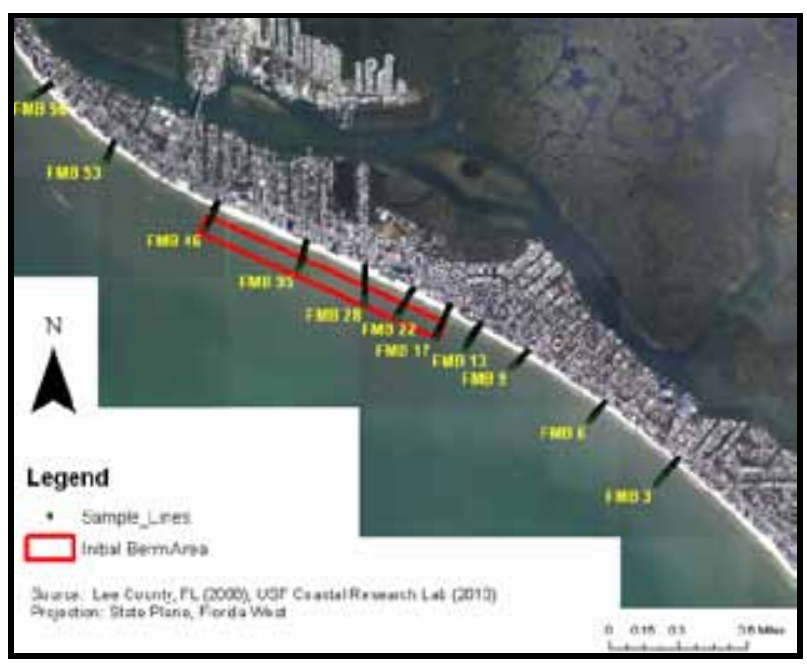

Figure 4. Locations of the sediment-sampling transects.

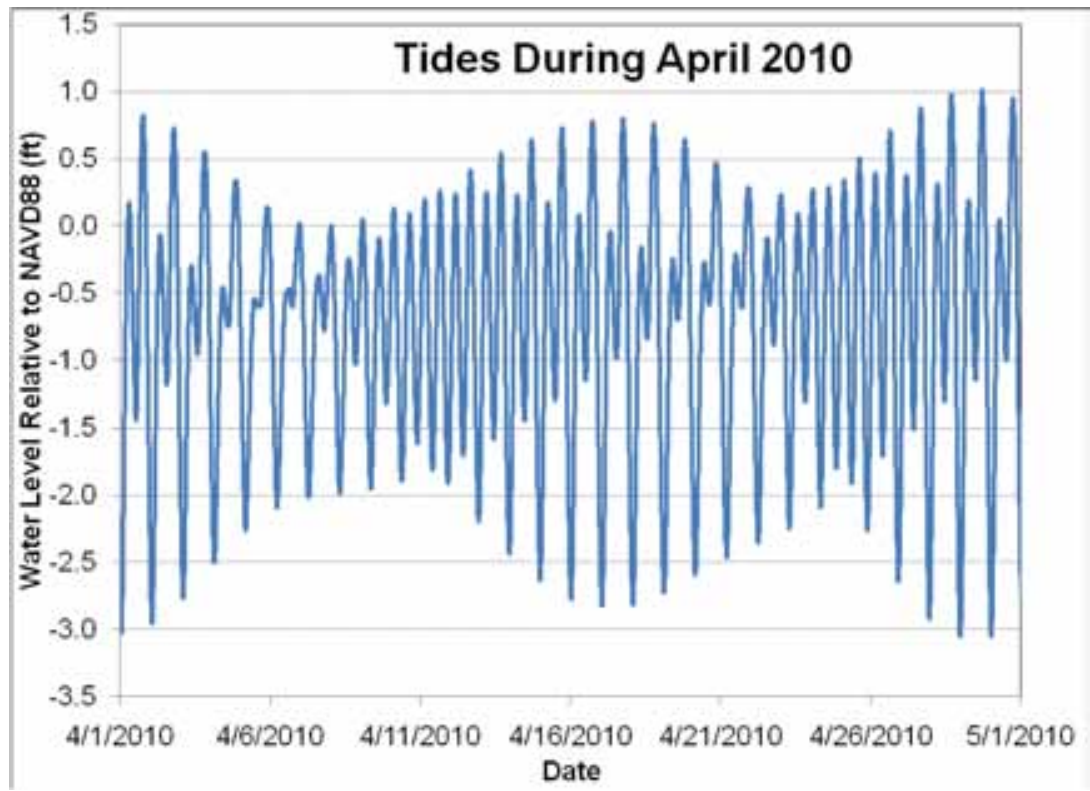

Figure 5. Measured tides during April 2010 at the NOAA Naples Station, approximately 20 miles south of the study area.

Table 1. Statistical wind conditions during the first year after berm construction, from October 2009 to October 2010.

\begin{tabular}{||l|l||l|l|l||}
\hline \hline & $\mathbf{1 3 0 - 1 7 5}$ deg. & $\mathbf{1 7 6 - 2 2 0}$ deg. & $\mathbf{2 2 1 - 2 6 5} \mathbf{\text { deg. }}$ & $\mathbf{2 6 6 - 3 1 0}$ deg. \\
\hline$\%<13 \mathrm{ft} / \mathrm{sec}$ & 61.1 & 95.1 & 69.9 & 55.4 \\
\hline$\% 13-23 \mathrm{ft} / \mathrm{sec}$ & 28.7 & 4.0 & 29.3 & 35.5 \\
\hline$\% 23-33 \mathrm{ft} / \mathrm{sec}$ & 8.9 & 0.9 & 0.5 & 7.3 \\
\hline$\%>33 \mathrm{~m} / \mathrm{sec}$ & 1.3 & 0.0 & 0.3 & 1.8 \\
\hline Avg. Speed $(\mathrm{ft} / \mathrm{sec})$ & 12.5 & 4.8 & 10.8 & 13.4 \\
\hline$\%$ of Total Wind & 10.8 & 4.9 & 7.1 & 8.9 \\
\hline
\end{tabular}


the southeast and northwest winds, which drive longshore transport in the opposite directions, are statistically similar (Table 1). No major tropic storm occurred during the first year after construction.

SEDIMENT CHARACTERISTICS: Typically, nine sediment samples were collected along transects in the control areas (Figures 6, 7, 10, and 11) and 11 samples along the profiles in the project area (Figures 8 and 9). Since the mud content is a key sediment quality parameter for this project, the following discussion focuses on the longshore and cross-shore variations of mud contents. Figures 6 and 7 show the percent of mud contents along representative profiles in the control area southwest of the artificial berm. Little mud, mostly less than one percent, was found on the dry beach. Some mud, mostly less than four percent, was found between mean sea level and about $4 \mathrm{ft}$ water depth. Significant mud content of up to 40 percent was found in surface sediments seaward of the $4 \mathrm{ft}$ contour.

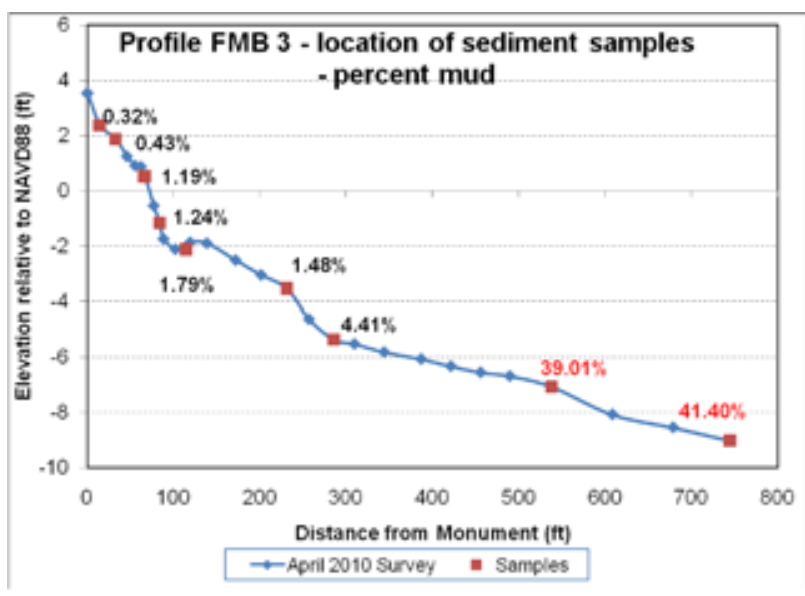

Figure 6. Beach profile of FMB3 (control), locations of surface sediment samples, and the percent of mud.

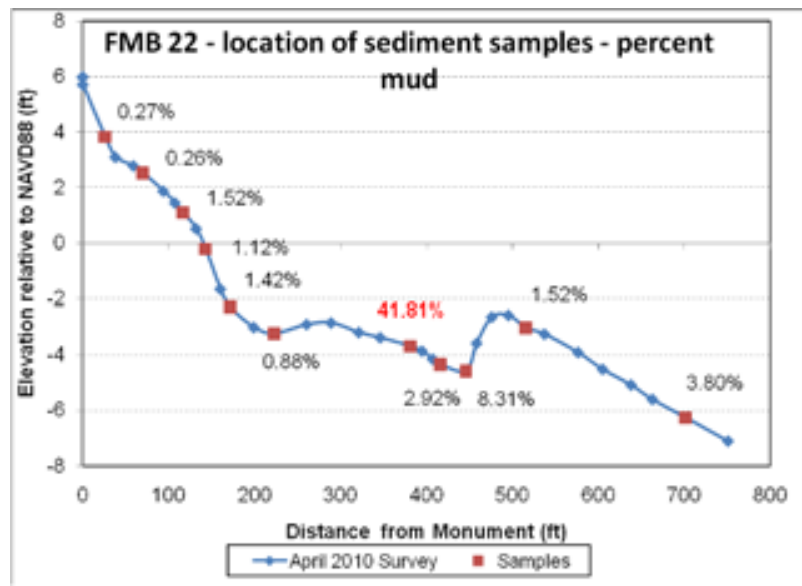

Figure 8. Beach profile of FMB22 (berm), locations of surface sediment samples, and the percent of mud.

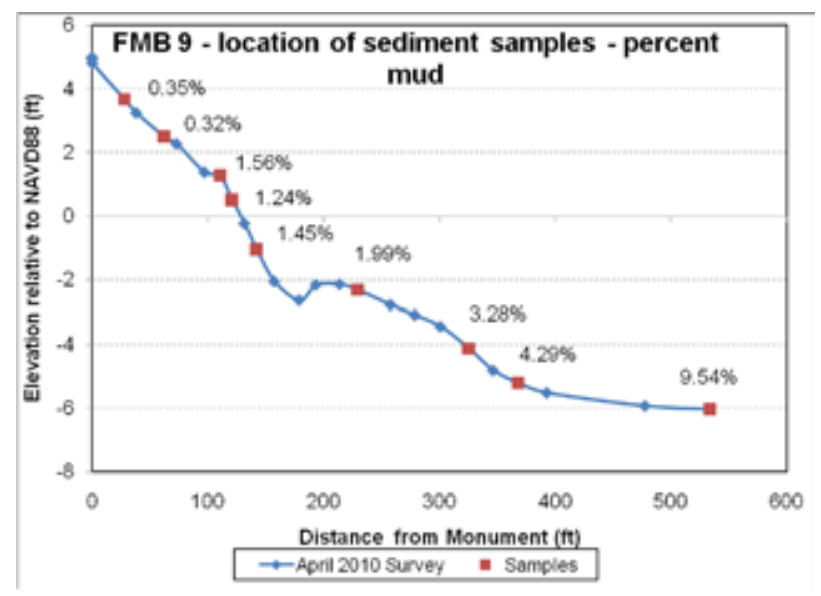

Figure 7. Beach profile of FMB9 (control), locations of surface sediment samples, and the percent of mud.

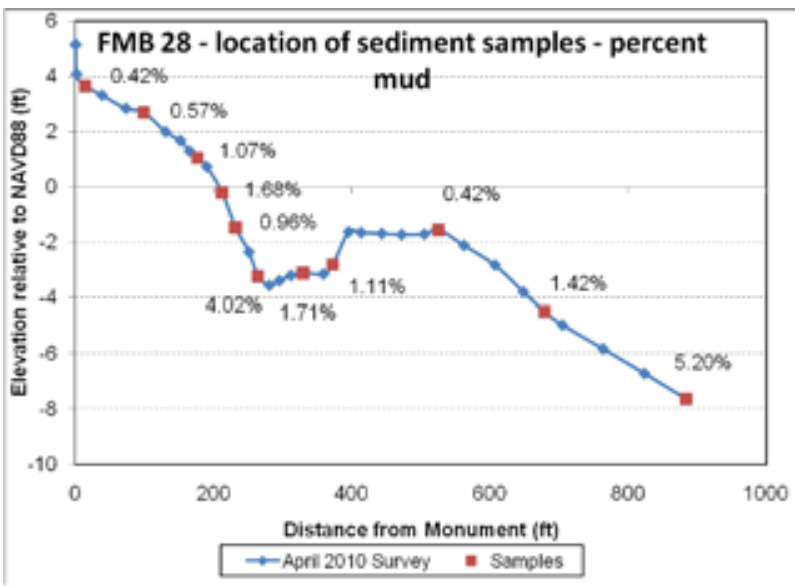

Figure 9. Beach profile of FMB28 (berm), locations of surface sediment samples, and the percent of mud. 


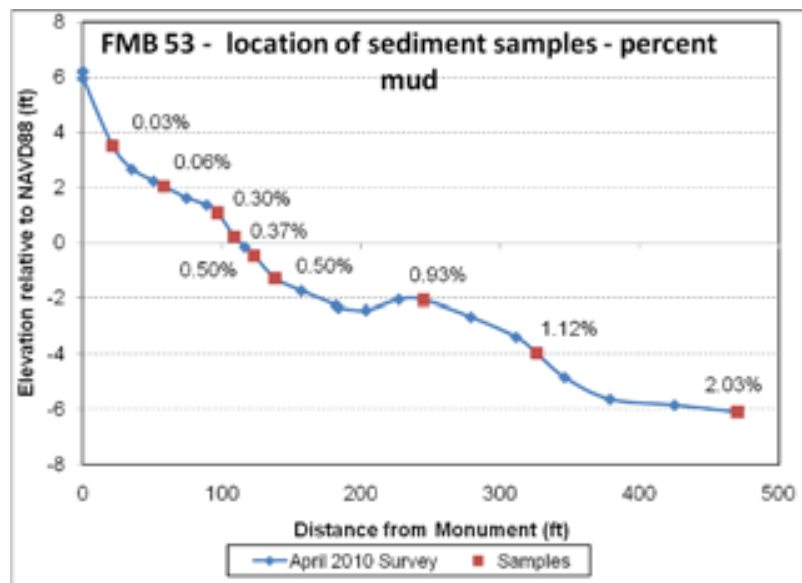

Figure 10. Beach profile of FMB53 (control), locations of surface sediment samples, and the percent of mud.

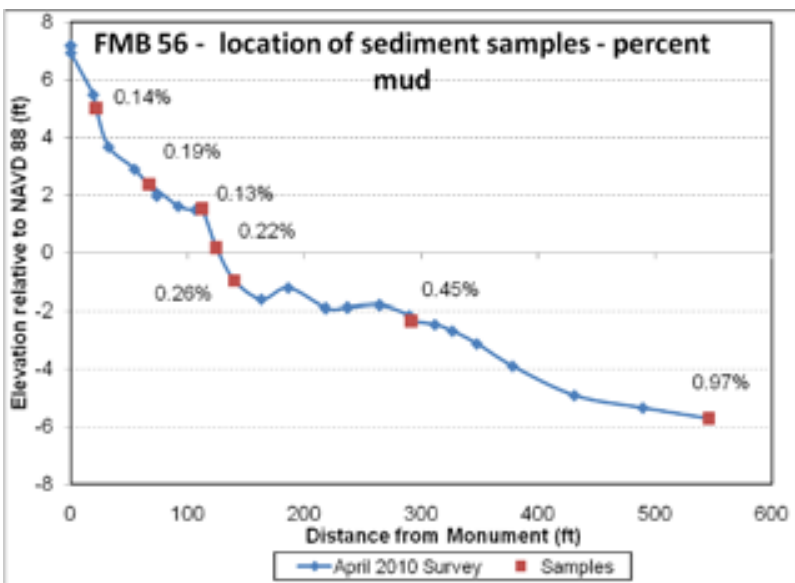

Figure 11. Beach profile of FMB56 (control), locations of surface sediment samples, and the percent of mud.

Less than two percent mud was found on the beach above mean sea level in the artificial berm area (Figures 8 and 9). Typically, less than three percent mud was found in the surface sediment on the berm. The highest mud content was found in the trough between the berm and the shoreline, ranging from one to four percent. A localized patch of muddy sediment was found in the trough of profile FMB22, with mud content of up to 41 percent. Compared to the control area to the southeast, the surface sediment in the offshore area is much less muddy, with less than four percent mud versus up to 40 percent mud. The surface sediment in the control area to the northwest of the artificial berm contains little mud, typically less than two percent, across the entire profile (Figures 10 and 11).

Generally, three types of sediment grain-size distribution patterns are distinguished in the surface sediments (Figure 12). Well-sorted fine sand is the dominant type of surface sediment on the dry beach, in the intertidal zone, and over the berm crest. Poorly-sorted shelly sand is found often in the swash zone. Poorly-sorted muddy sand is found on the surface of the offshore area southeast of the berm. Patches of muddy sand are found in the trough between the berm and shoreline.

MORPHOLOGICAL EVOLUTION: The first-year morphologic evolution was examined by comparing the Jacksonville District (USACE) October 2009 post-construction survey with the USF April and October 2010 surveys. Figure 13 shows profile FMB18, located on the southeastern edge of the berm. The berm height at FMB18 is relatively low at about $2 \mathrm{ft}$ and remains constant during the first year. The overall profile-volume stays rather constant, indicating that cross-shore sediment transport dominates in the first year. During the first 6 months, the overall morphology, i.e., the two bars, was maintained while the entire system migrated onshore for about $100 \mathrm{ft}$. The beach and nearshore area landward of the artificial berm remained stable over the initial 6-month period. The beach profile evolution during the second 6 months was different from the first 6 months, in that the small bar that was close to the shoreline migrated and attached to the shoreline, resulting in a modest beach accretion at this site (Figure 13).

Different from the case at the southeastern edge (FMB18), throughout most of the project area, the berm height measured from the bottom of the trough to the crest of the bar is approximately $3 \mathrm{ft}$ (Figure 14). The lower berm height near the terminus of the project (Figure 13) is controlled likely 


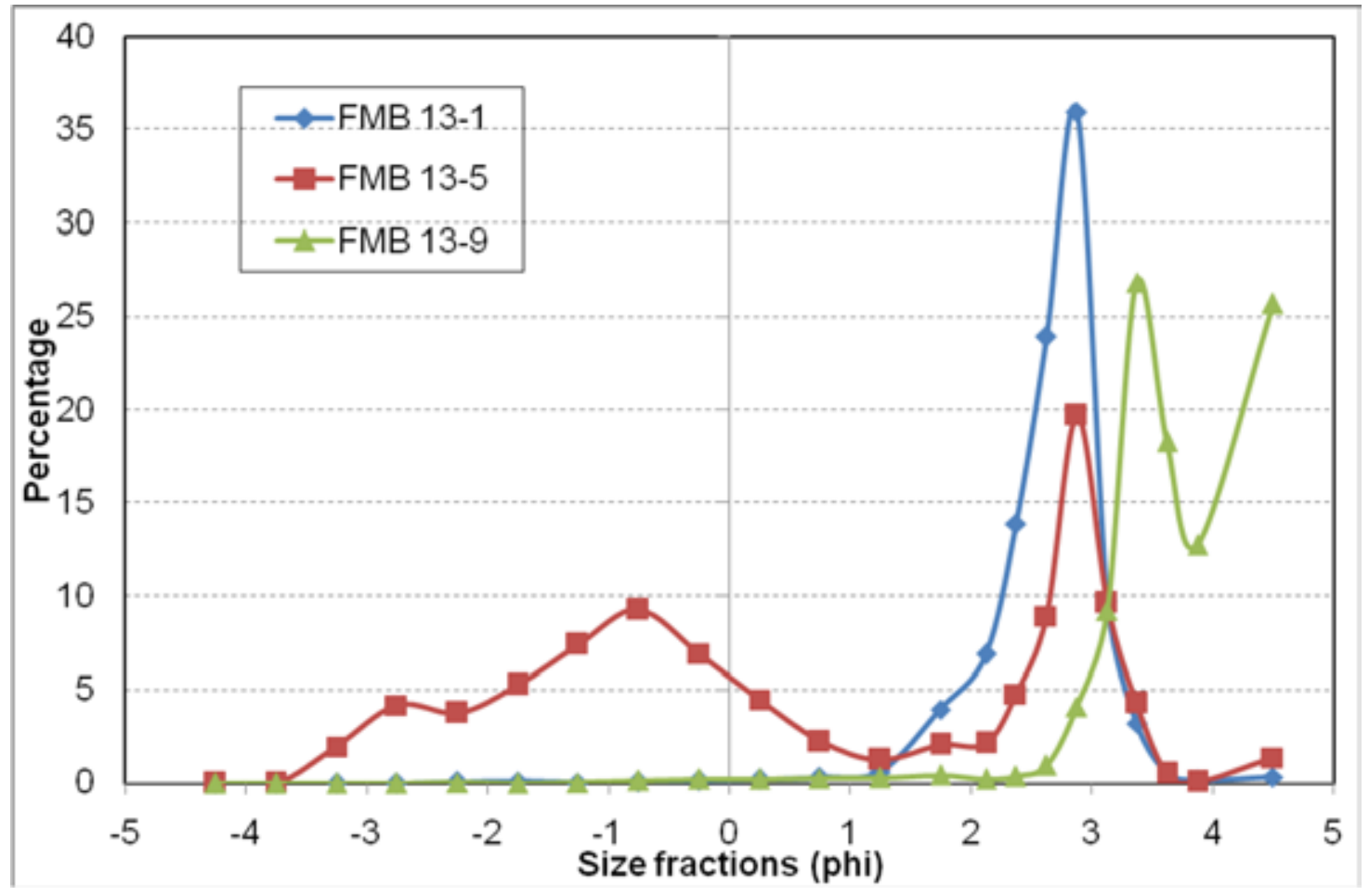

Figure 12. Typical grain-size distribution of the surface sediment. FMB13-1 is an example of well-sorted fine sand. FMB13-5 illustrates poorly-sorted shelly sand. FMB 13-9 shows poorly-sorted muddy sand.

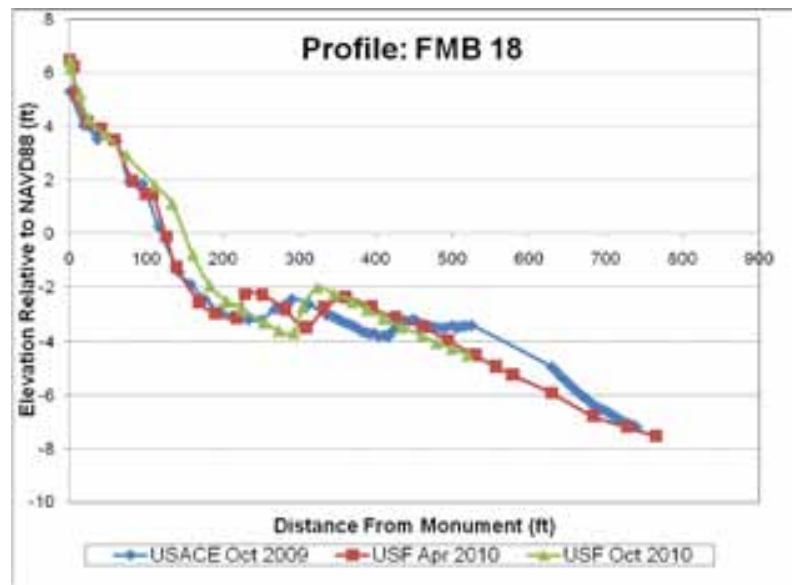

Figure 13. Time series beach profile at FMB 18

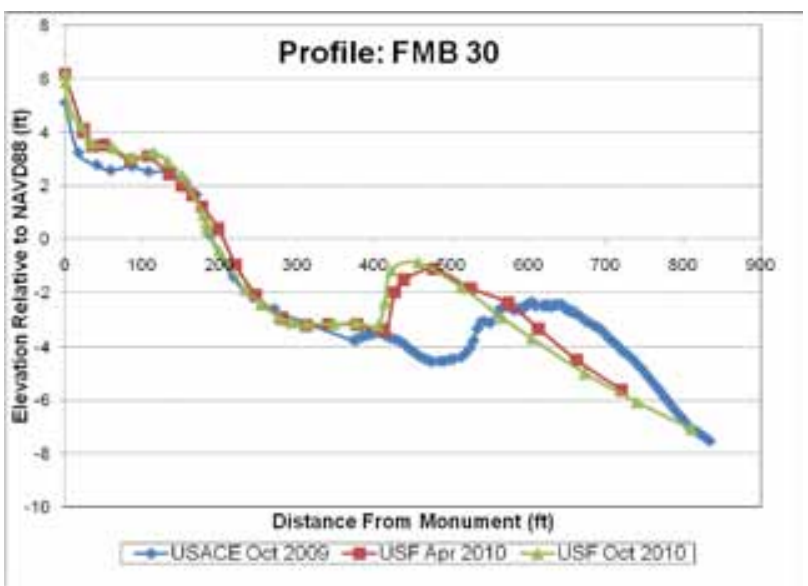

Figure 14. Time-series beach profile at FMB30.

by the construction. The constructed berm height was maintained during the first year. Within the central portion of the project area, most of the profiles over the berm illustrated an onshore migration of nearly $200 \mathrm{ft}$ during the first 6 months (Figure 14). Profile FMB30 is located roughly in the middle of the artificial berm project area. In addition to onshore migration, the berm crest elevation has increased by approximately $1.5 \mathrm{ft}$ at this location, while the berm height remained largely similar. The shape of the berm has changed from a roughly symmetrical bell curve to a sharply skewed bar with a steep landward slope. The total volume of the berm was roughly maintained as it migrated landward and upward, with erosion on the seaward slope and deposition 
in the prior trough location. The landward migration continued during the second 6 months but at a much reduced rate, while maintaining the skewed shape of the berm (Figure 14). The beach and nearshore area landward of the artificial berm remained stable over the first year after the construction.

A small nearshore bar less than 2-ft high exists along the beach profiles in the control area southeast of the artificial berm (Figure 15). The height and volume of this bar are much smaller than those of the artificial berm. The bar migrated approximately $60 \mathrm{ft}$ onshore during the first 6 months. Different from the artificial berm case, the onshore migration of the bar resulted from modest erosion at both the seaward slope and in the nearshore zone, instead of just at the seaward slope for the artificial berm. The dry beach remained stable. Nearly no change occurred during the second 6-month period.

Compared to the profiles discussed above, FMB 54, located to the northwest of the artificial berm, demonstrates a different trend of evolution (Figure 16). Except for a small amount of accumulation in the trough area, erosion occurred across nearly the entire profile during the first 6 months. This profile is rather close to the recently dredged Mantazas Pass and may be influenced by inlet processes. During the second 6 months, the small bar (less than $1 \mathrm{ft}$ high) that was developed in the previous trough moved offshore to roughly the location of the prior bar, while the dry beach remained stable. Overall, the magnitude of the profile changes during the year is small.

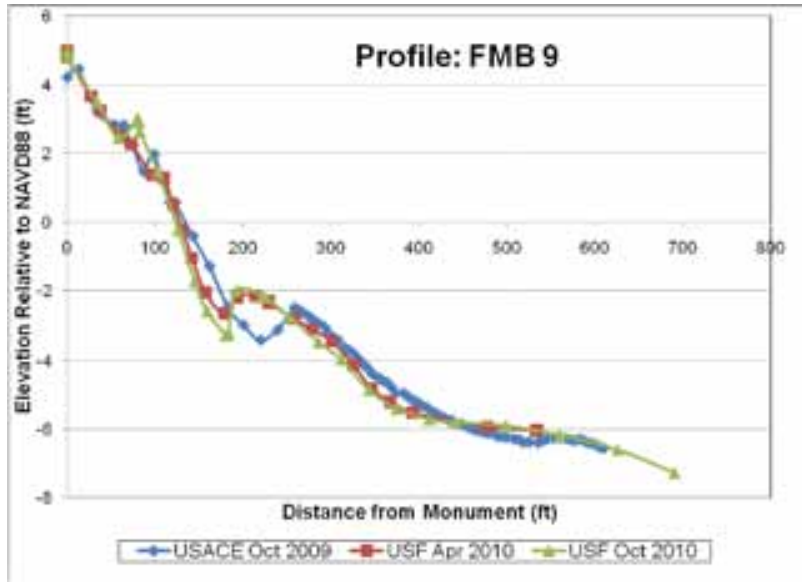

Figure 15. Time-series beach profile at FMB9.

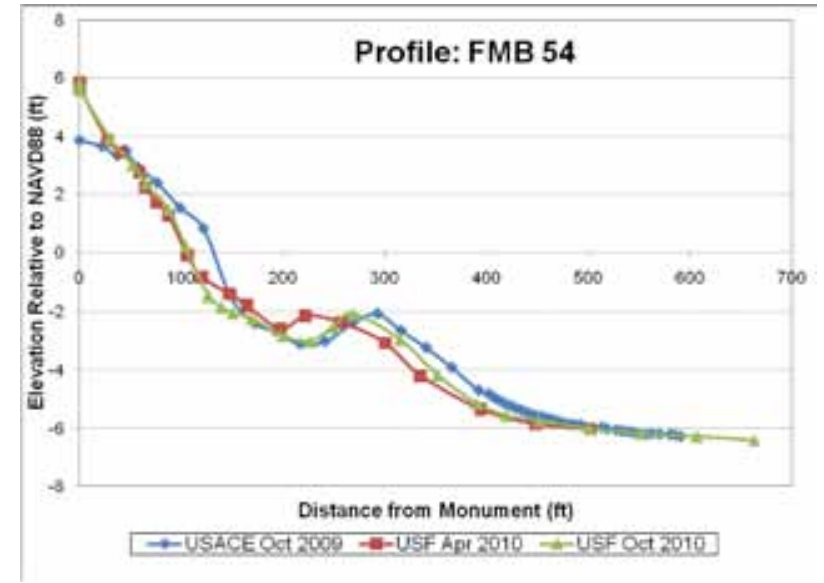

Figure 16. Time-series beach profile at FMB54.

In summary, the artificial berm migrated landward for approximately 150 to $200 \mathrm{ft}$ with an increase in berm crest elevation of roughly 1.0 to $1.5 \mathrm{ft}$ during the first 6 months after the construction. The landward migration continued during the second 6 months, but at a much reduced rate. The shoreline landward of the artificial berm remained mostly stable during the first year. Onshore migration of a much smaller natural bar was measured in the control areas. However, the migration distance, typically less than $120 \mathrm{ft}$, is considerably smaller than that of the artificial berm

Substantial longshore variation of the artificial berm was measured. Figure 17 shows all 30 profiles across the artificial berm referred to the mean high high water level (MHHW). Based on the NOS tide station at Naples, the MHHW is at $0.58 \mathrm{ft}$ NAVD88 for the study area. As evident from the 
plot of all the profiles referred to the MHHW line (Figure 17), longshore variations occur in every part of the profile, including from land to sea, the foreshore slope, the location and depth of the trough, the location, height, and width of the berm, and the depth and slope of the seaward flank.

A relationship is identified between the distance of the berm crest to the location of the MHHW and the elevation of the berm crest: a lower berm crest corresponds to a longer distance to the MHHW line, while an increasing berm elevation corresponds with a decreasing distance to the MHHW line (Figure 18). However, the relationship is qualitative and localized. Similar berm height does not correspond to similar distance to MHHW line at a different longshore location. Figure 18 also illustrates that there are several locations where the berm crest elevation is relatively low. These gaps are not exactly spaced equally but are not completely irregular, and also tend to vary in elevation (or water depth). It is worth noting that some gaps were constructed during the berm placement.

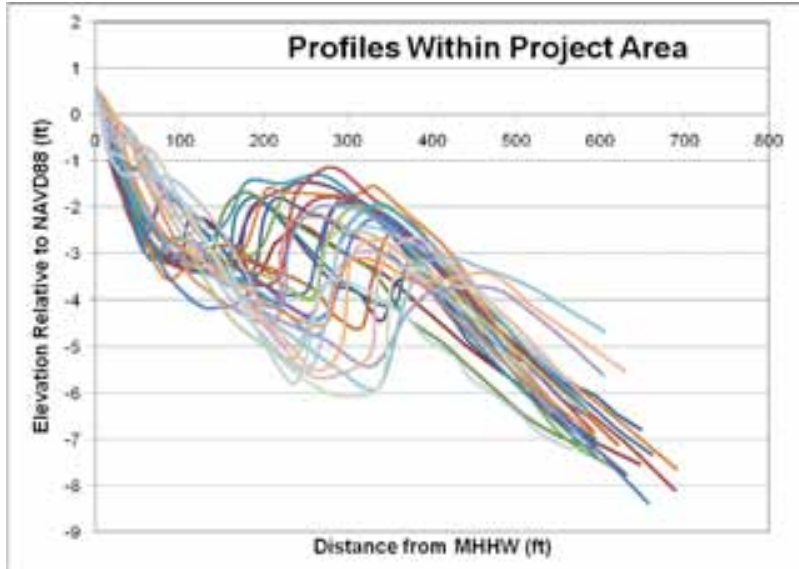

Figure 17. All 30 profiles across the artificial berm, referred to the MHHW line. Note the substantial longshore variation of the morphology.

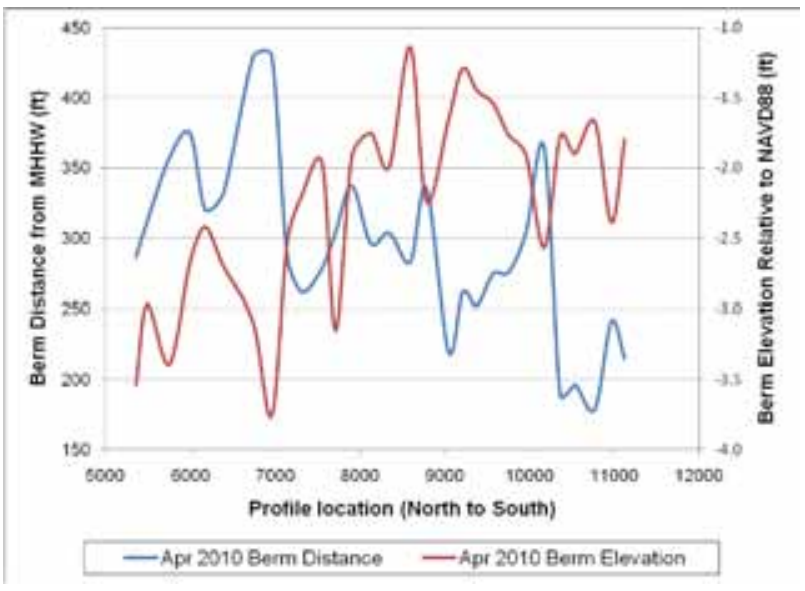

Figure 18. Longshore variation of the distance of the berm crest to MHHW line (berm distance) and the berm crest elevation. Profile location is referred to the distance to the northeastern most profile.

Considerable changes in longshore variations of the berm crest elevation occurred between April and October 2010 (Figure 19). Overall, the berm crest elevations have increased, reflecting the general trend of onshore and upward migration. Several of the profiles were not surveyed in October 2010. Despite some missing data, it is apparent that the locations of some of the gaps have changed from April to October 2010 (Figure 19), indicating that the gaps are dynamic. They are likely maintained as rip channels during high-wave conditions. The movement of the gaps may be driven by the spatial variations of the rip cells. Future studies will verify the presence and dynamics of the rip cells. Given the generally low-wave conditions of the study area, significant rip cells should occur only under high wave-energy conditions.

Overall, the artificial berm has moved onshore, mostly less than $50 \mathrm{ft}$, during the second 6 months, with considerable longshore variations (Figure 20, green line). Abnormal distance changes were measured in the vicinity of the gaps due to the longshore movement of the gaps. The above spatial analysis was not conducted for the immediate post-construction survey due to a lower spatial resolution. 


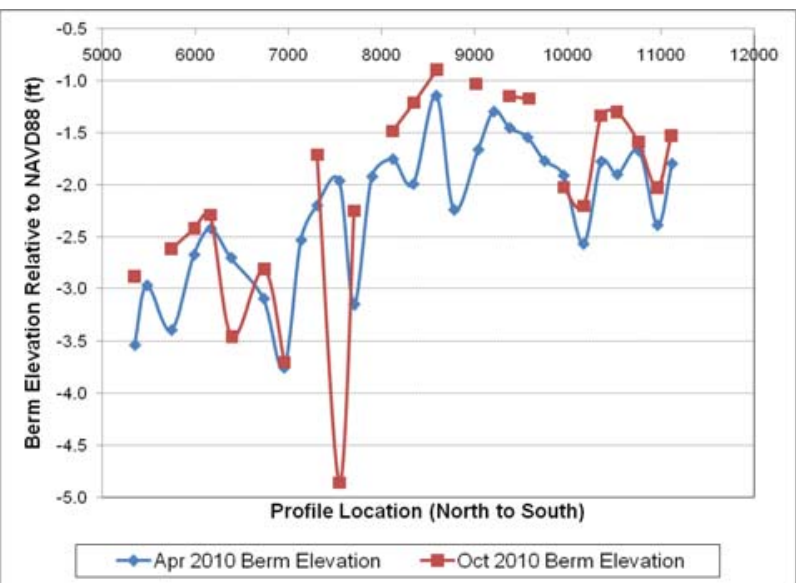

Figure 19. Longshore variations of berm crest elevation in April and October 2010. Profile location is referred to the distance to the northeastern most profile (FMB57).

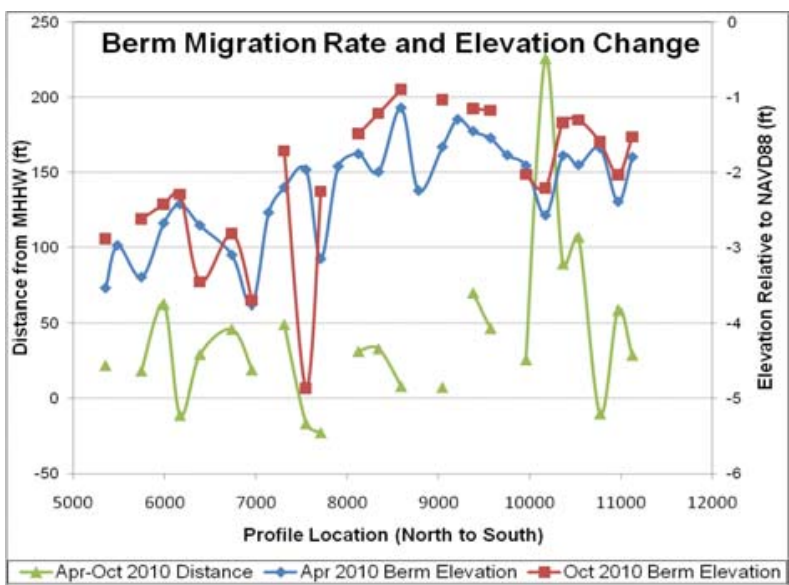

Figure 20. Longshore variations of berm crest elevation, and changes in distance from berm crest to MHHW line (green line). Profile location is referred to the distance to the northeastern most profile.

CONCLUSIONS: The artificial berm at Fort Myers Beach is composed mostly of fine sand. Patches of muddy surface sediment, with up to 40 percent of mud, was found in the trough just landward of the berm. During the first year after the construction, the berm migrated approximately 150 to $200 \mathrm{ft}$ onshore, with a roughly 1.0 to $1.5 \mathrm{ft}$ increase in the berm crest elevation. The onshore migration occurred mostly during the first 6 months. The shape of the berm has changed from a constructed semi-symmetrical bell curve to a highly asymmetrical bar with a steep landward slope, the typical morphology of an onshore migrating bar. The height of the constructed berm, measured from the trough bottom to the berm crest, remained similar during the first year, despite the onshore migration, increased berm crest elevation, and bar-shape change. During the following 6 months, the onshore migration continued but at a much reduced rate. The morphology of the artificial berm illustrates considerable longshore variation, segmented by several gaps of varying depth. Although the gaps were initiated during the construction, they are dynamic and have moved alongshore on the order of 150 to $300 \mathrm{ft}$. It is likely that the gaps are maintained by rip cells during high wave-energy events.

ADDITIONAL INFORMATION: This CHETN is a product of the Geomorphology Work Unit of the Coastal Inlets Research Program (CIRP) and the Regional Sediment Management Program (RSM), conducted at the U.S. Army Engineer Research and Development Center, Coastal and Hydraulics Laboratory. Data collection and analysis were completed by Dr. Ping Wang and Katherine Brutsche at the University of South Florida under contract with the U.S. Army Engineer Research and Development Center. Detailed information about the planning and engineering of the project and valuable discussion about project results were provided by James W. Lagrone, USACE Jacksonville District. Questions about this CHETN can be addressed to either Dr. Ping Wang (Phone: 813-974-9170, e-mail: pwang@usf.edu), or Tanya M. Beck (Phone: 601-634-2603, e-mail: (Tanya.M.Beck@usace.army.mil). For information about the CIRP, please contact the CIRP program manager, Dr. Julie D. Rosati, at 251-694-3719 or Julie.D.Rosati@usace.army.mil; Linda Lillycrop is the RSM program manager and can be reached at 301-427-2431 or Linda.S.Lillycrop@usace.army.mil. 


\section{REFERENCES}

Aidala, J. A., C. E. Burke, and T. N. McLellan. 1996. Hydrodynamic Forces and Evolution of a Nearshore Berm at South Padre Island, Texas. Proceedings of the Hydraulic Engineering Sessions at Water Forum '91, American Society of Civil Engineers, pp 1234-1239.

Allison, M. C., and C. B. Pollock. 1993. Nearshore Berms: An Evaluation of Prototype Designs, Coastal Zone '93. American Society of Civil Engineers, pp 2938-2950.

Florida Department of Environmental Protection, 2009. <http://bcs.dep.state.fl.us/envprmt/lee/issued/o15889.3_Matanzas_Pass_Maintenance_Dredging/oo5-JC/>.

Hallermeier, R. J. 1981. A Profile Zonation for Seasonal Sand Beaches from Wave Climate. Coastal Engineering, Vol. 4, No. 3, pp 253-277.

Hands, E. B., and M. C. Allison. 1991. Mound Migration in Deeper Water and Methods of Categorizing Active and Stable Depths. Proceedings of Coastal Sediments '91, American Society of Civil Engineers, pp 1985-1999.

McLellan, T. N., and N. C. Kraus. 1991. Design Guidance for Nearshore Berm Construction, Proceedings of Coastal Sediments '91. American Society of Civil Engineers, pp 2000-2011.

Larson, M., and N. C. Kraus. 1992. Analysis of Cross-shore Movement of Natural Longshore Bars and Material Placed to Create Longshore Bars. U.S. Army Corps of Engineers Technical Report DRP92-5, $89 \mathrm{p}$.

Work, P. A., and E. N. Otay. 1996. Influence of Nearshore Berm on Beach Nourishment. Proceedings of Coastal Engineering 1996, American Society of Civil Engineers, pp 3722-3735.

NOTE: The contents of this technical note are not to be used for advertising, publication,

or promotional purposes. Citation of trade names does not constitute an official endorsement or approval of the use of such products. 